\title{
Mengkaji Film The Curious Case of Benjamin Button dengan Semiotika
}

\author{
Dian Rinjani \\ Program Studi Pendidikan Multimedia, Kampus UPI di Cibiru \\ Universitas Pendidikan Indonesia \\ Jl. Raya Cibiru Km 15 Bandung 40393 \\ Email: dianrinjani@upi.edu
}

\begin{abstract}
ABSTRAK
Film merupakan salah satu bidang yang relevan bagi analisis semiotika. Analisis semiotik pada film berlangsung pada teks yang merupakan struktur dari produksi tanda. Bagian struktur penandaan dalam film biasanya terdapat dalam unsur tanda paling kecil, dalam film disebut scen. Penelitian ini dilakukan dengan menggunakan pendekatan kualitatif. Pendekatan ini dianggap sesuai, dengan prosedur yang dilakukan peneliti, menghasilkan data deskriptif berupa kata kata yang dihasilkan dari mengamati tanda tanda berupa visual, gambar bergerak, bahasa tubuh dan audio/suara yang terdapat dalam film The Curious of Benjamin Button. Ruang lingkup penelitian ini adalah beberapa potongan adegan yang mewakili film The Curious of Benjamin Button. Bisa ditarik kesimpulan bahwa di dalam sebuah film seperti The Curious of Benjamin Button penonton bisa membaca tanda yang diberikan oleh pemeran pemeran film The Curious of Benjamin Button. Melalui tanda-tanda seperti suara, gerakan tubuh, raut muka, tampilan tokoh-tokoh dan lainnya yang ada di dalam film, penonton dapat menyimpulan isi sebuah film dari tanda tanda yang diberikan oleh sutradara selama film berlangsung. Oleh karena itu dalam membuat film seperti pengambilan gambar dan semua unsur-unsur yang ada didalam sebuah film tidak bisa dibuat dengan sembarangan. Apabila pembuatan film dibuat sembarangan cerita atau maksud dari sutradara tidak akan tersampaikan dengan baik.
\end{abstract}

Kata kunci: Film, Semiotika, Proxemics, Visual, Tanda.

\begin{abstract}
Film is one of the relevant fields for semiotic analysis. The semiotic analysis of the film takes place in the text which is the structure of the sign production. Part of the marking structure in a film is usually contained in the smallest sign element, in a film called a scen. This research was conducted using a qualitative approach. This approach is considered appropriate, with the procedure carried out by the researcher, producing descriptive data in the form of words produced from observing signs in the form of visual, moving images, body language and audio / sound contained in the film The Curious of Benjamin Button. The scope of this research are several scenes that represent the film The Curious of Benjamin Button. It can be concluded that in a film like The Curious of Benjamin Button, the audience can read the sign given by the cast of the film The Curious of Benjamin Button. Through signs such as sound, body movements, facial expressions, the appearance of characters and others in the film, the audience can conclude the contents of a film from the signs given by the director during the film. Therefore, in making films such as taking pictures and all the elements in a film cannot be made carelessly. If the filmmaking is made carelessly the story or the director's intentions will not be conveyed properly.
\end{abstract}

Keywords: Films, Semiotics, Proxemics, Visuals, Signs

\section{Pendahuluan}

Film merupakan salah satu bidang yang relevan bagi kajian semiotika. Film adalah salah satu yang dihasilkan dari gambar-gambar bergerak yang disatukan. Di dalam film memiliki tanda-tanda Seperti yang dikemukakan Art Van Zoest, film dibangun dengan tanda-tanda semata. Tanda-tanda itu termasuk berbagai sistem tanda yang bekerjasama dengan baik untuk mencapai efek yang diharapkan. Berbeda dengan tanda-tanda fotografi statis, rangkaian tanda dalam film menciptakan imajinasi atau sistem penandaan. Pada film digunakan tanda-tanda ikonis yaitu tanda-tanda yang menggambarkan seseuatu. Gambar yang dinamis pada sebuah film merupakan ikonis bagi realitas yang dinotasikannya.[1]

Kajian semiotika pada film berlangsung pada teks yang merupakan struktur dari produksi tanda. Bagian struktur penandaan dalam film biasanya terdapat dalam unsur tanda paling kecil, dalam film 
disebut scene. Scene dalam film merupakan satuan terkecil dari struktur cerita film atau biasa disebut alur. Alur sendiri merupakan sejumlah motif satuan-satuan fiksional terkecil yang terstruktur sedemikian rupa sehingga mampu mengembangkan tema serta melibatkan emosi-emosi. Sebuah alur biasanya mempunyai fungsi estetik pula, yakni menuntun dan mengarahkan perhatian penonton ke dalam susunan motif-motif tersebut.

Analisis semiotik berupaya menemukan makna tanda termasuk hal - hal yang tersembunyi dibalik sebuah tanda (teks, iklan, berita). Karena sistem tanda sifatnya sangat kontekstual dan bergantung pada pengguna tanda tersebut. Pemikiran pengguna tanda merupakan hasil pengaruh dari berbagai konstruksi sosial di mana pengguna tanda tersebut berada.[2]

Setiap sutradara memiliki pengaruh yang berbeda pada setiap film, tergantung bagaimana latar belakangnya. Salah satu latar belakang yang memperngaruhi hasil karyanya antara lain lingkungan seperti tempat dia dibesarkan, kumunitas, pengalaman dan masih banyak faktor lainnya. Film yang dihasilkan setiap sutradara biasanya mempunyai ciri khas tersendiri. Ciri khas sutradara yang satu dengan yang lainnya berbeda-beda. Perbedaannya bisa mereka perlihatkan dari visual, teks, atau teknologi film yang digunakan. Semua itu bisa menjadi gagasan dalam pembuatan film.

Di dalam teori semiotika komunikasi, proses pemaknaan gagasan, pengetahuan atau pesan secara fisik disebut representasi. Secara lebih tepat ini didefinisikan sebagai penggunaan tanda - tanda untuk menampilkan ulang sesuatu yang dicerap, diindra, dibayangkan atau dirasakan dalam bentuk fisik.[3]

Sebenarnya cerita pada film tidak hanya merupakan refleksi dari realitas kehidupan masyarakat yang dipindahkan dalam sebuah karya semata melainkan film juga dijadikan media represntatif dari kehidupan masyarakat. Didalam film tidak hanya cerita saja yang di tampikan melainkan kode-kode dan idiologi dari kebudayaan. Menurut Stuart Hall, film sebagai sebuah konsep representasi memiliki beberapa definisi fungsi, yaitu menunjuk, baik pada proses maupun produksi pemaknaan suatu tanda. Representasi juga menjadi penghubung makna dan bahasa dengan kultur. Selain itu, makna dikonstruksi oleh sistem representasi dan diproduksi melalui sistem bahasa yang fenomenanya bukan hanya melalui ungkapan-ungkapan verbal tapi juga visual.

Di dalam salah satu karya David Fincher yang berjudul The Curious Case of Benjamin Button menceritakan tentang seorang pria yang dilahirkan berbeda dengan kebanyakan orang. Kehidupannya terbalik seperti jam besar yang ada di stasiun kereta api di New Orleans yang dibuat oleh seorang lelaki yang bernama Clockmaker Gateau (Koteas) yang biasa di panggil Mr. Cake Jam yang dibuat oleh Mr. Cake berputar kebalikan dari jam kebanyakan, jam tersebut berputar kearah kiri. Jam ini bentuk dari harapan dia mengulang kembali waktu yang sudah terjadi. Dalam film ini banyak memiliki kode-kode, dan idiologi dari kebudayaan di beberapa negara yang membuat penontonnya terbawa emosi dan terhanyut dalam film tersebut.

\section{Metode Penelitian}

\subsection{Semiotika sebagai Metode Penelitian}

Semiotika sendiri berasal dari kata yunani semeion yang berarti tanda. Setiap manusia selalu mencari tanda atau memahami segala macam tanda yang ada di lingkungan sekitarnya, baik disengaja maupun tidak disengaja. Salah satu cabang keilmu yang sering menggunakan ilmu semiotika diantaranya desain komunikasi visual. Cabang keilmuan ini sering menggunakan ilmu semiotika dikarenakan objek yang sering mereka pakai dalam dunia desain komunikasi visual untuk menyampaikan pesan pada masyarakat luas atau kalangan masyarakat tertentu adalah dengan gambar atau visual. Dimana semiotika berperan sekali dalam menyampaikan tanda tanda yang dapat di tangkap oleh masyarakat.

\subsection{Pendekatan Penelitian}

Penelitian ini akan dilakukan dengan menggunakan pendekatan kualitatif. Pendekatan ini dianggap sesuai, dengan prosedur yang dilakukan peneliti, menghasilkan data deskriptif berupa kata kata yang dihasilkan dari mengamati tanda tanda berupa visual, gambar bergerak, bahasa tubuh dan audio/suara yang terdapat dalam film The Curious of Benjamin Button. 


\subsection{Ruang Lingkup Penelitian}

Ruang lingkup penelitian ini adalah beberapa ptongan adegan yang mewakili film The Curious Of Benjamin Button dari audio dan visual. Unit kajian data dalam penelitian ini adalah potongan potongan visual, gambar dan suara yang menunjukkan adanya tanda yang menyiratkan arti pada beberapa adegan dan suara dalam film The Curious of Benjamin Button.

\section{Hasil dan Pembahasan}

\section{SINOPSIS FILM THE CURIOUS OF BENJAMIN BUTTON}

Film ini di sutradarai oleh David Fincher, film ini diadaptasi dari sebuah cerita pendek karya $F$. Scott Fitzgerald dengan judul yang sama. Walaupun berkisah tentang sesuatu yang tak mungkin terjadi, sebenarnya film ini bicara tentang hakikat kehidupan dan apa yang dialami manusia sedari ia lahir hingga berakhir di liang kubur. Dan lebih dari itu semua, film ini bicara tentang cinta.

Untuk menuangkan cerita pendek karya $F$. Scott Fitzgerald ini sang sutradara memerlukan durasi sepanjang kurang lebih 2 jam 47 menit. Pada saat pengerjaan film ini, sutradara tidak membuatnya dengan terburu-buru. Efek yang ingin dicapai memang bukan sekedar menceritakan kasus aneh yang dialami Benjamin Button namun lebih pada proses perubahan fisik dan mental yang dialami Benjamin agar penonton bisa ikut merenungi pergulatan batin yang dialami sang tokoh utama.

Pada awal cerita dalam film ini seorang wanita sedang membaca sebuah buku harian yang berisi foto dan kartu pos yang ditulis oleh Benjamin Button. Wanita ini bernama Daisy, dia dibacakan buku ini oleh anaknya yang bernama Caroline. Mereka berdua berada di rumah sakit New Orleans, pada bulan agustus 2005 .

Dalam buku tersebut ini menceritakan tentang perjalanan hidup seorang pria bernama Benjamin Button (Brad Pitt) terlahir di tahun 1860. Kelahiran bocah ini tergolong kasus yang sangat aneh. Awal cerita, suatu hari pada tanggal 11 November 1918, orang-orang di New Orleans merayakan akhir 'Great War'. (Kemenangan dari Perang Dunia I), di waktu yang sama terlahir bayi laki-laki terlahir dengan tampilan fisik seperti seorang lelaki berusia 80 tahun-an. Ibu dari bayi tersebut meninggal sesaat setelah melahirkan. Ayahnya (Thomas Button) membawa bayi tersebut dan meninggalkannya disebuah rumah panti jompo. Queenie dan Tizzy Pasangan keturunan AfrikaAmerika bekerja di panti jompo, yang menemukan bayi tersebut. Queenie tidak bisa mengandung oleh karena itu dia memutuskan untuk membawa bayi tersebut dan dianggap sebagai anaknya sendiri. Bayi tersebut diberi nama Benjamin.

Dikisahkan bahwa Benjamin ternyata mengalami pembalikan proses penuaan. Dari usia tujuh puluh tahun, perlahan Benjamin tumbuh menjadi lebih muda. Proses pembalikan usia ini ternyata malah membuat kehidupan Benjamin menjadi lebih rumit. Selama hidupnya benjamin dianggap laki-laki tua walaunpun sebenarnya dia masih sangat muda. Dalam perjalanan hidupnya Benjamin bertemu dengan banyak orang, dan mengajarkannya segala sesuatu yang belum pernah dia lakukan. Seperti bekerja di sebuah kapal penarik di dermaga New Orleans bersama Kapten Kapal Mike. Kapten Mike meperkenalkannya pada wanita di lokalisasi. Kemudian betertemu dengan ayahnya kembali tanpa dia mengetahui sebenarnya dia berhadapan dengan ayahnya sendiri. Seorang gadis yang bernama Daisy yang menjadi ibu dari anaknya. Benjamin bertemu seorang wanita Inggris yang bernama Elizabeth Abbott dan akhirnya Benjamin jatuh cinta untuk pertama kalinya. Untuk pertama kalinya Benjamin melihat kematian yang berbeda dari biasanya (di panti jompo yang mana kematian nya lebih alami) ketika kapten Mike mati tertembak di Atlantik dan berkata "tembakannya telah merusak keindahan tatonku". Benjamin harus menyaksikan kematian dari orang-orang yang dia cintai.

Keadaan jadi semakin sulit setelah Benjamin menikah dan memiliki putri. Bukannya tumbuh menjadi makin tua, Benjamin menjadi semakin muda dan akhirnya kembali menjadi anak-anak. Selama proses pemudaannya banyak sekali yang dia alami sampai akhirnya dia mati di panti jompo di mana dia tinggal dulu. 


\section{TEORI DAN ANALISIS}

Dalam film ini yang sangat menonjol adalah mengenai waktu yang seperti berjalan mundur untuk kehidupan Benjamin. Dimana semua orang semakin bertambah usia semakin fisiknya terlihat tua, sedangkan dia semakin bertambah usia semakin muda bentuk fisiknya. Dia terlahir dengan bentuk fisik yang tua dan semua penyakit yang dialami oleh orang yang berumur tua sedagkan Benjamin mati dalam bentuk fisik bayi. Penanda waktu yang menjadi terbalik ini memandakan perbedaan kesehatan (kelainan fisik) yang di miliki oleh Benjamin dan tidak dimiliki oleh manusia normal lainnya.

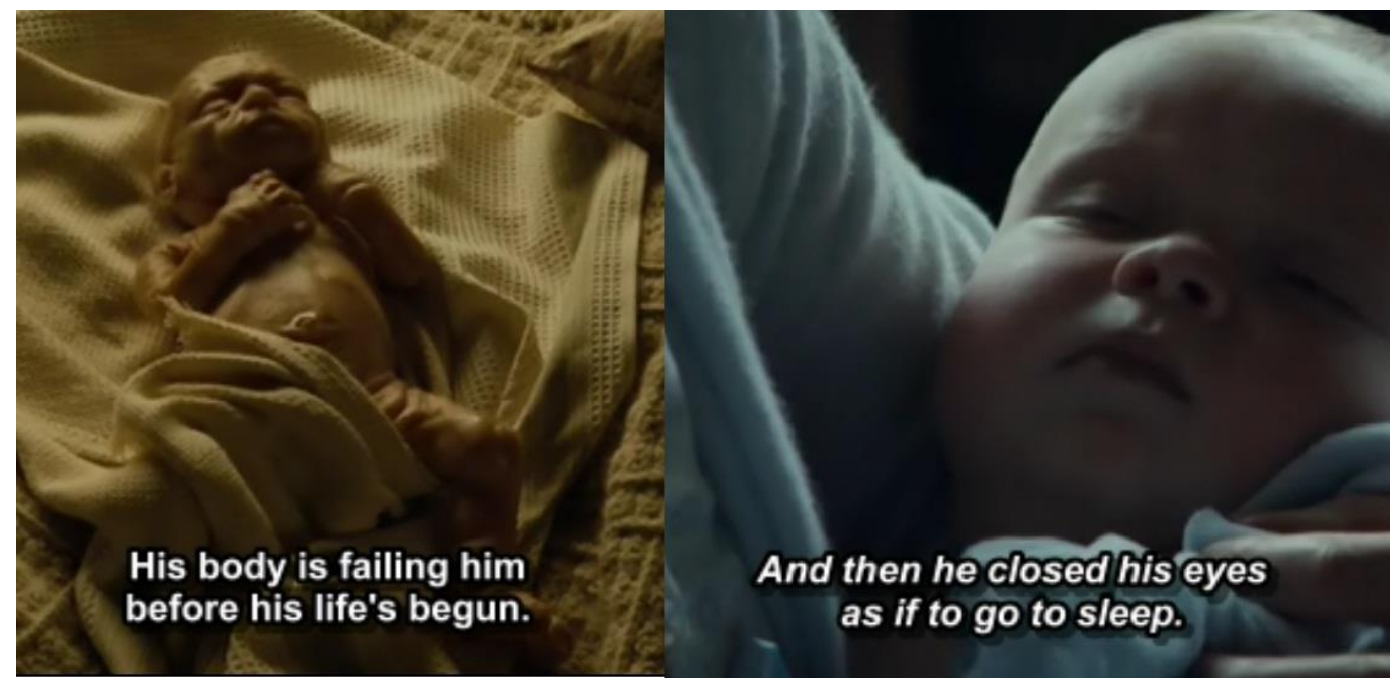

Gambar 1. Benjamin pada saat baru lahir (kiri), Benjamin pada saat meninggal (kanan)

Film ini diceritakan dengan alur mundur, Caroline (anak Benjamin) menceritakan kembali kisah dari buku harian Benjamin. Selain alur cerita yang mundur tetapi juga menceritakan kehidupan Benjamin yang semakin mengalami kemunduran menjadi lebih muda. Caroline dan penonton bisa merasakan bagaimana perjalanan hidup Benjamin dengan tanda-tanda yang tinggalkan di dalam buku harian tersebut. 


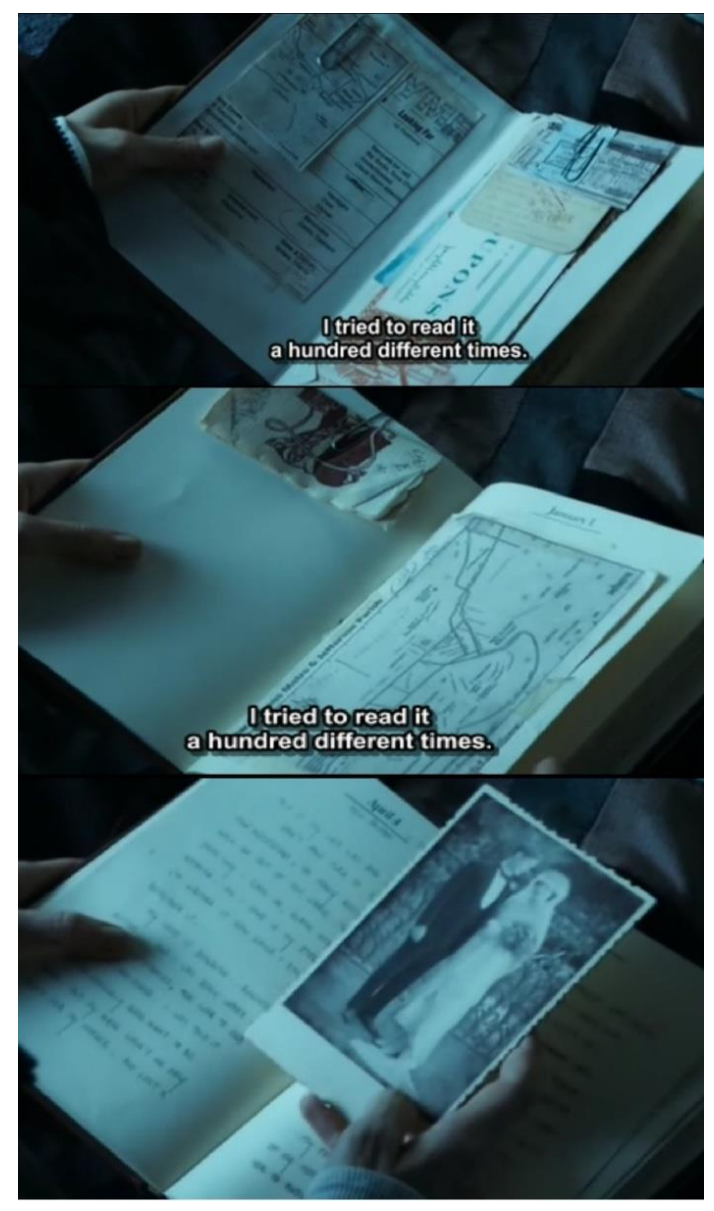

Gambar 2. Buku harian Benjamin Button

Dalam film ini diperlihatkan ada semiotic of space atau disebut dengan proxemics. Ketika Daisy datang lagi ke panti jompo untuk menemui Benjamin yang sudah menjadi anak kecil dan lupa sipapun yang pernah dia kenali. Ketika Daisy mencoba untuk menyentuh Benjamin, dia menghindar dan tidak mau di sentuh siapapun karena merasa tidak mengenal siapapun yang ada idana. Benjamin terus memperkenalkan dirinya pada Daisy. Disini menjamin menunjukkan ketidak sukaannya di sentuh atau berdekatan dengan orang yang dia tidak kenal. Seperti yang dijelaskan pada teori proxemics dibawah ini.

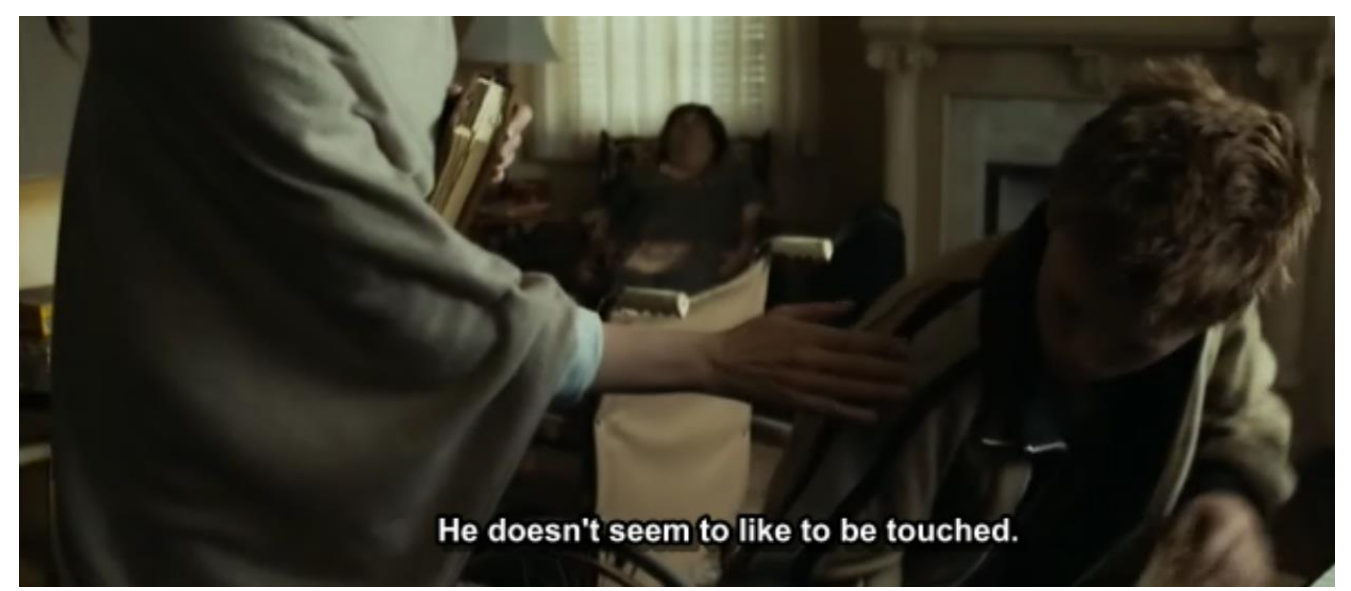

Gambar 3. Adegan Benjamin akan disentuh Daisy pada saat dia sudah mulai lupa dengan banyak hal 
Menurut Edward T. Hall's manusia mempunyai jarak yang berbeda-beda tergantung kedekatan terhadap sesama manusia yang lainnya, seperti dibawah ini:

1. Jarak intim untuk merangkul, menyentuh atau berbisik Jarak dekat - kurang dari 6 inci $(15 \mathrm{~cm})$ Jarak jauh - 6 sampai 18 inci $(15-46 \mathrm{~cm})$

2. Jarak pribadi untuk interaksi antara teman-teman baik atau anggota keluarga Jarak dekat - 1,5 sampai 2,5 kaki $(46-76 \mathrm{~cm})$

Jarak jauh - 2,5 sampai 4 kaki $(76-120 \mathrm{~cm})$

3. Jarak sosial untuk interaksi antar kenalan Jarak dekat - 4 sampai 7 kaki $(1,2-2,1 \mathrm{~m})$ Jarak jauh - 7 sampai 12 kaki $(2,1-3,7 \mathrm{~m})$

4. Jarak publik yang digunakan untuk berbicara di depan umum Jarak dekat - 12 sampai 25 kaki $(3,7-7,6 \mathrm{~m})$ Jarak jauh - 25 kaki $(7,6 \mathrm{~m})$ atau lebih.

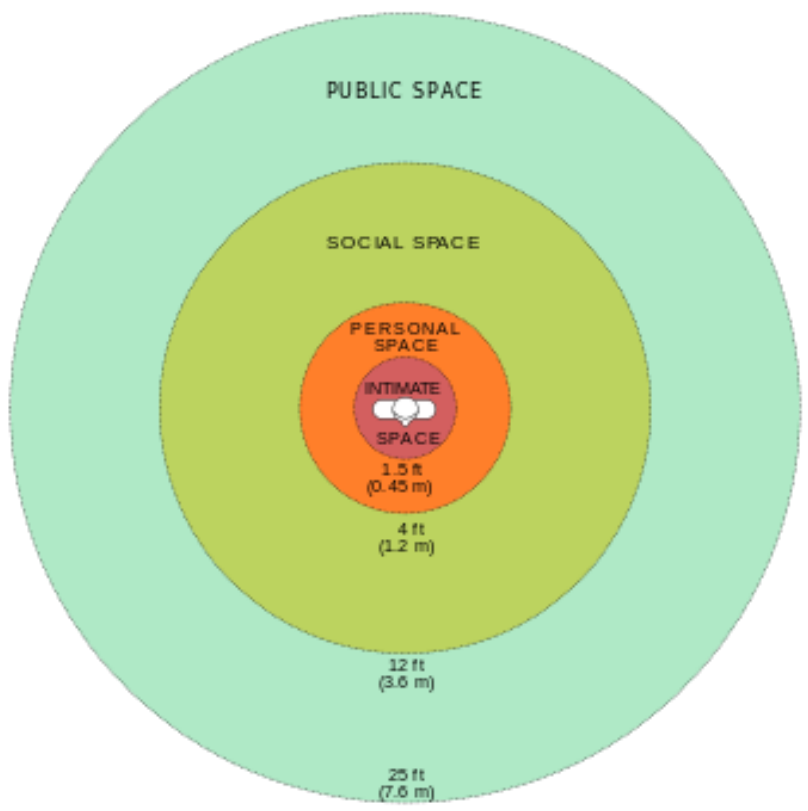

Gambar 4. Proxemics menurut Edward T. Hall's 'personal reaction bubbles' (1966)

Dalam adegan yang lain, saat Benjamin ditemukan di tangga rumah jompo oleh Queenie dan suaminya, kedua orang ini tidak sengaja menginjak bayi tersebut dan memperlihatkan muka kaget dan menjauh. Menadakan mereka merasa asing dengan benda (bayi) tersebut, maka mereka membuat jarak dengan benda tersbut sampai mengetahui apa yang mereka injak sebenarnya.

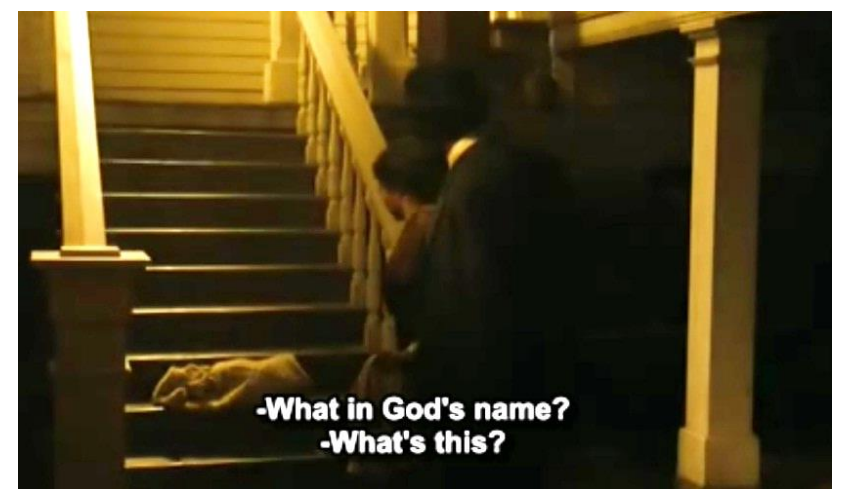

Gambar 5. adegan Benjamin terinjak oleh Queenie dan suaminya 
Saussure mendefinisikan tanda linguistik sebagai entitas dua sisi (dyad). Sisi pertama disebutkan dengan penanda (signifier). Penanda adalah aspek material dari sebuah tanda, sebagaimana kita menangkap bunyi saat orang berbicara. Bunyi ini muncul dari getaran pita suara (yang tentu saja bersifat material), Saussure menjelaskan penanda verbal sebagai "citra bunyi. Sisi kedua dari tanda yaitu sisi yang diwakili secara material oleh penanda adalah apa yang disebut Saussure sebagai petanda (signified).[4]

Dengan suara bisa menadakan keberadaan seseorang di satu tempat untuk mendapatkan perhatian di sekitarnya. Seperti yang dilakukan di dua adegan dalam film di bawah ini ketika Queenie mengumumkan kehadiran Benjamin di panti jompo dan ketika dia mengumumkan kehamilannya pada saat semua orang sedang berkumpul.

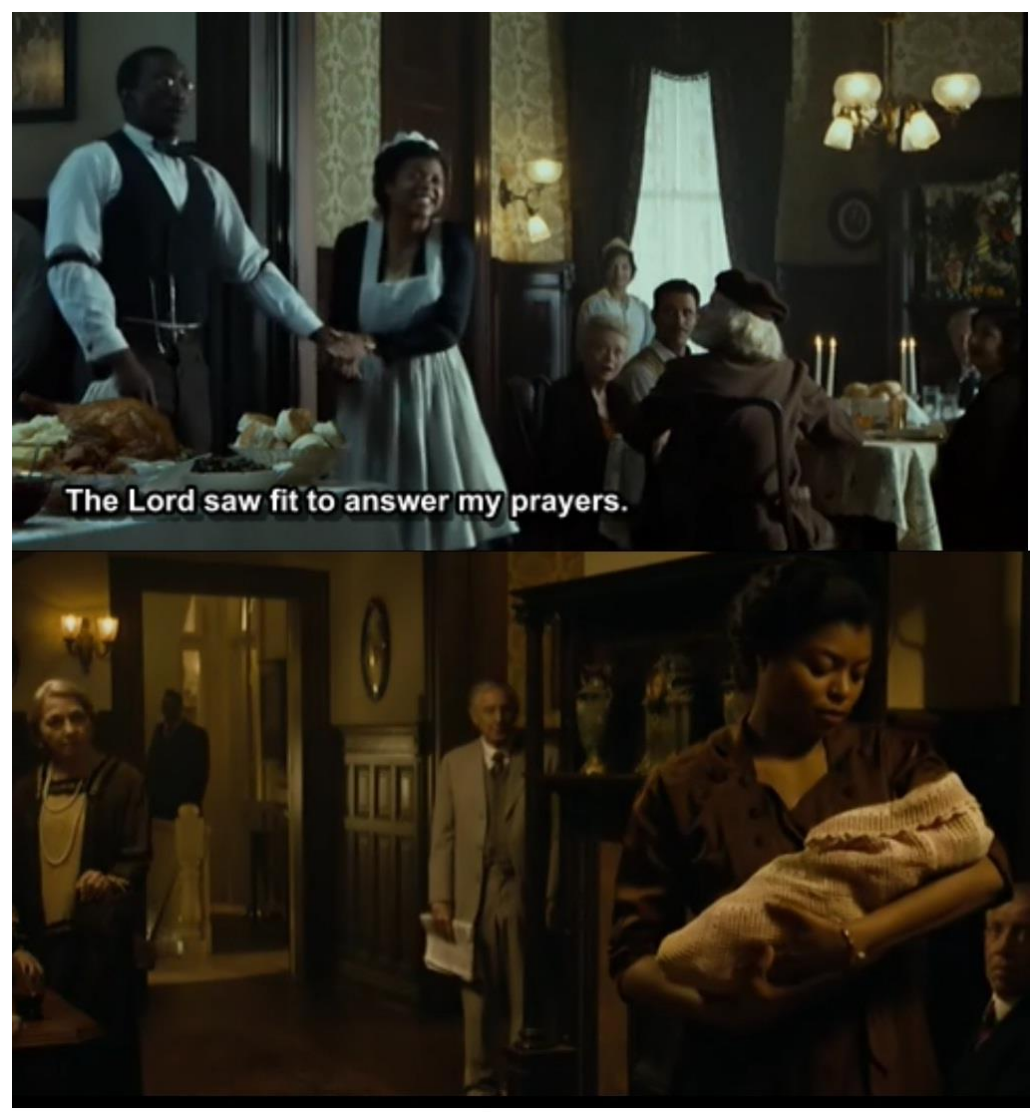

Gambar 6. Queenie menginformasikan sesuatu di panti jompo

Penanda yang lain di film ini seperti pada saat kematian ibu kandung dari Benjamin. Dalam adegan ini yang digunakan shot close-up memperlihatkan wajah ibunya dengan jelas. Wajah ibu tersebut pucat dengan bibir berwarna pucat, rambutnya basah, lemah, seperti tidak betenaga. Penanda ini menunjukkan bahwa ibu kandung Benjamin sedang kelelahan setelah melahirkan dan tidak bisa bertahan lama dan meninggal. Selain itu yang menggunaka shot close-up, ketika ayah Benjamin berniat untuk membuang Benjamin ke laut dan diketahui oleh seorang polisi. Muka Thomas di closeup untuk memperlihatkan kepanikan dari dirinya yang tertangkap basah ingin membuang bayinya ke laut. 


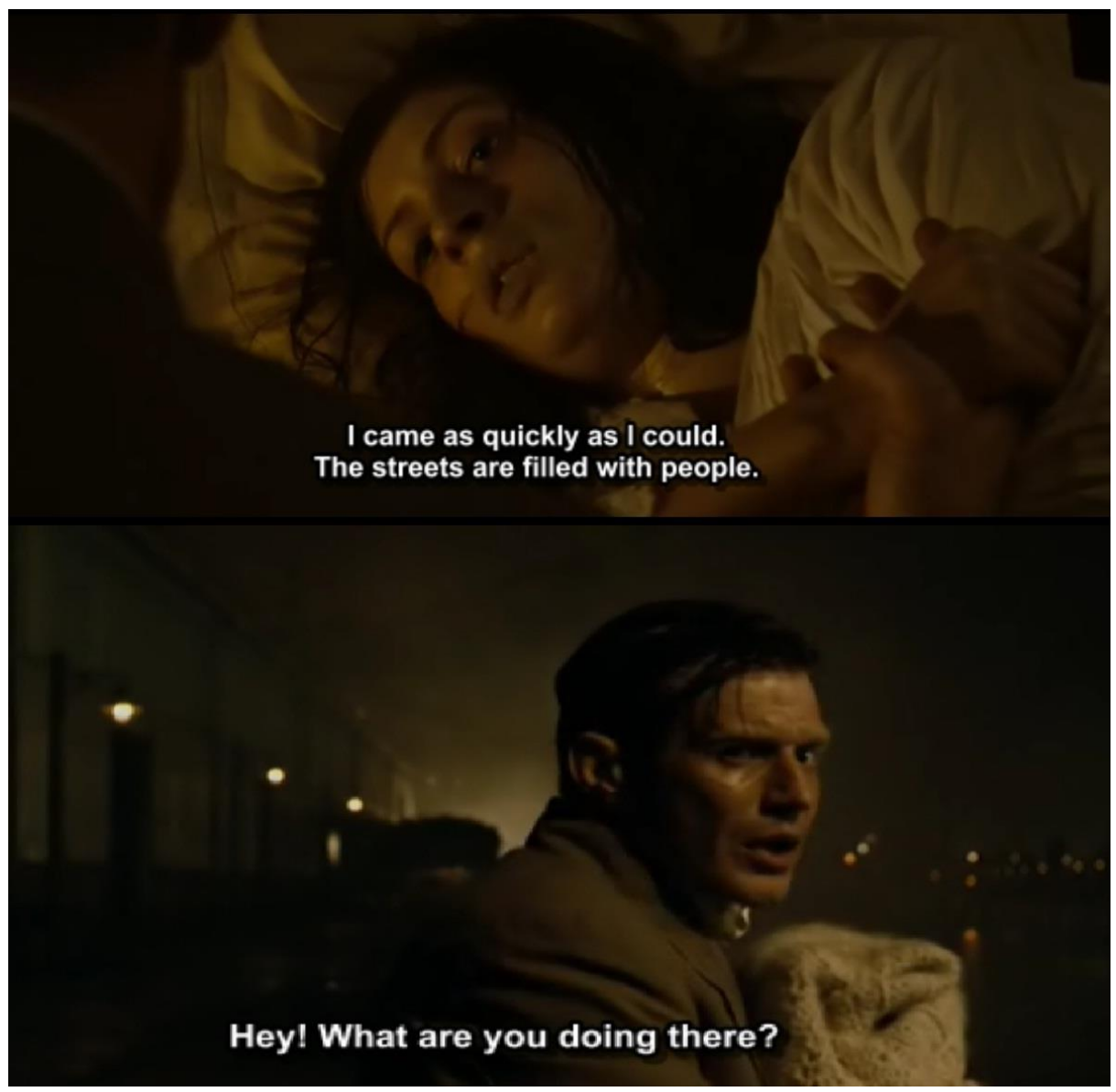

Gambar 7. Ibu kandung Benjamin yang sedang sekarat (atas), Ayah Benjamin yang berniat membuangnya (bawah)

\section{Simpulan}

Dilihat secara keseluruhan penjelasan diatas bisa ditarik kesimpulan bahwa di dalam sebuah film seperti The Curious of Benjamin Button penonton bisa membaca tanda yang diberikan oleh pemeran pemeran film The Curious of Benjamin Button. Melalui tanda-tanda seperti suara, gerakan tubuh, raut muka, tampilan tokohtokoh dan lainnya yang ada di dalam film, penonton dapat menyimpulan isi sebuah film dari tanda tanda yang diberikan oleh sutradara selama film berlangsung. Oleh karena itu dalam membuat film seperti pengambilan gambar dan semua unsur-unsur yang ada didalam sebuah film tidak bisa dibuat dengan sembarangan. Apabila pembuatan film dibuat sembarangan cerita atau maksud dari sutradara tidak akan tersampaikan dengan baik. Saran peneliti untuk kedepannya, pembutan sebuah film akan lebih baik bila menggunakan pendekatan semiotika komukasi, agar mengahasilkan film-film yang bisa dimengerti penonton hanya denan menggunakan tanda tanda.

\section{Daftar Pustaka}

1. Rachmat Kriyantono, Teknik praktis riset komunikasi, (Jakarta: Prenada Media Group, 2008), Hlm. 263.

2. Marcel Danesi, Pengantar Memahami Semiotika Media, (Yogyakarta: Jalasutra, 2010), hlm. 3.

3. Alex Sobur, Semiotika Komunikasi, (Bandung: Remaja Rosda Karya, 2003), hlm.128

4. Paul Cobley dan Litza Jansz, Mengenal Semiotika for Beginners, (Bandung: Mizan, 2002), hlm. 10. 